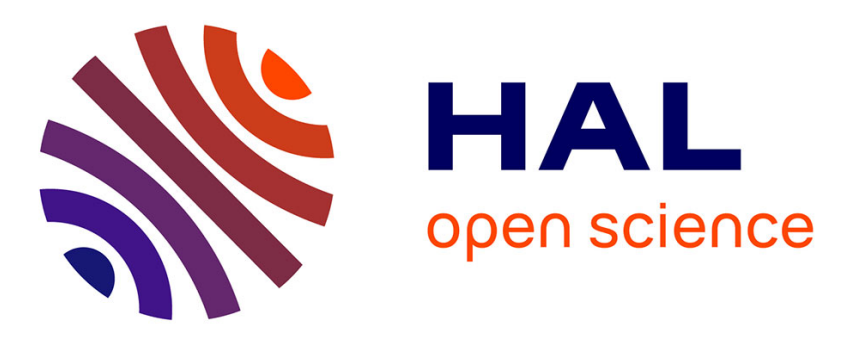

\title{
Cyclometallated platinum(II) complexes containing pyridyl-acetylide ligands: the selective influence of lead binding on luminescence
}

\author{
Pierre-Henri Lanoe, Hubert Le Bozec, J. A. Gareth Williams, Jean-Luc \\ Fillaut, Véronique Guerchais
}

\section{To cite this version:}

Pierre-Henri Lanoe, Hubert Le Bozec, J. A. Gareth Williams, Jean-Luc Fillaut, Véronique Guerchais. Cyclometallated platinum(II) complexes containing pyridyl-acetylide ligands: the selective influence of lead binding on luminescence. Dalton Transactions, 2010, 39 (3), pp.707-710. 10.1039/B914957K . hal-00917226

\section{HAL Id: hal-00917226 \\ https://hal.science/hal-00917226}

Submitted on 11 Dec 2013

HAL is a multi-disciplinary open access archive for the deposit and dissemination of scientific research documents, whether they are published or not. The documents may come from teaching and research institutions in France or abroad, or from public or private research centers.
L'archive ouverte pluridisciplinaire HAL, est destinée au dépôt et à la diffusion de documents scientifiques de niveau recherche, publiés ou non, émanant des établissements d'enseignement et de recherche français ou étrangers, des laboratoires publics ou privés. 


\title{
Cyclometallated platinum(II) complexes containing pyridyl-acetylide ligands: the selective influence of lead binding on luminescence $\uparrow$
}

\author{
Pierre-Henri Lanoë, ${ }^{a}$ Hubert Le Bozec, ${ }^{a}$ J. A. Gareth Williams, ${ }^{b}$ Jean-Luc Fillaut ${ }^{* a}$ and Véronique Guerchais ${ }^{* a}$
}

Received 23rd July 2009, Accepted 29th September 2009

First published as an Advance Article on the web 12th October 2009

DOI: 10.1039/b914957k

The design, synthesis, photophysical properties, and the ionbinding properties of cyclometallated platinum(II) complexes containing pyridyl-appended alkynyl ligands are described. When the pyridyl group is incorporated into an azamacrocycle, a specific response towards lead(II) cations involves a change in the nature of the excited charge transfer state, resulting in the appearance of a low-energy absorption band and a partial quenching of luminescence.

Extensive work has been devoted to transition metal based systems capable of the detection of changes in the local environment, including temperature, pressure, partial pressure of gases and volatile organic compounds, cations and anions. ${ }^{1-12}$ In particular, cyclometallated polypyridyl $\mathrm{Pt}(\mathrm{II})$ complexes incorporating $\sigma$ alkynyl ligands ${ }^{13}$ are considered to be candidates of interest as vapochromic, vapoluminescent $t^{14}$ and solution-based luminescent sensors. One successful strategy used to construct long-lived and luminescent cyclometallated platinum(II) sensors involves functionalization of the acetylide ligand by an ion receptor. ${ }^{15-24} \mathrm{We}$ have been exploring the chemistry and binding properties of luminescent platinum(II) compounds incorporating an ethynylflavone moiety. These complexes were found to bind lead(II) ions leading to an unprecedented switch from phosphorescence to fluorescence. ${ }^{25}$ In these systems, the electronic effect of the acetylide substituent

${ }^{a}$ Sciences Chimiques de Rennes UMR 6226 CNRS-Université de Rennes 1, Avenue du Général Leclerc, 35042, Rennes Cedex France. E-mail: jeanluc.fillaut@univ-rennes1.fr, veronique.guerchais@univ-rennes1.fr; Fax: +33(0)2232369 39; Tel: +33(0)223235952

${ }^{b}$ Department of Chemistry, University of Durham, South Road, Durham, DH13LE, United Kingdom.E-mail: j.a.g.williams@durham.ac.uk

$\dagger$ Electronic supplementary information (ESI) available: Experimental procedures and spectral characterization data for new compounds. See DOI: $10.1039 / \mathrm{b} 914957 \mathrm{k}$ controls the charge transfer by modulating the energy of the filled Pt-based orbitals, allowing a high tunability of the emission energies of the Pt(II) complexes. We anticipated that the presence of a pyridyl-appended $\sigma$-alkynyl ligand, acting as a metal ion receptor via the nitrogen atom of the pyridine ring whilst electronically connected to the Pt center via the $\mathrm{C} \equiv \mathrm{C}$ bond, would allow tuning of the photophysical properties of the complex and an alternative sensing strategy. In order to provide increased metal cation affinity and higher selectivity, the incorporation of a pyridyl unit within a macrocycle should be beneficial. ${ }^{26-28}$

In this contribution, we describe the synthesis of new platinum(II) complexes $\mathbf{1}$ and $\mathbf{2}$ (Chart 1) using this design strategy based on alkynyl-pyridine ligands. The ion-binding properties of 1 towards various metal cations $\left(\mathrm{Mg}^{2+}, \mathrm{Ba}^{2+}, \mathrm{Pb}^{2+}, \mathrm{Ni}^{2+} \mathrm{Zn}^{2+}, \mathrm{Cd}^{2+}\right)$ have been investigated. A specific response towards lead(II) cations results in a change in the nature of the emissive state manifest as a partial quenching of luminescence, probably arising from a rare example of a switch of CT in the opposite direction.

Cyclometalated phenylbipyridyl platinum(II) acetylide complexes $\left[\mathrm{Pt}\left({ }^{t} \mathrm{Bu}_{2}-C^{\wedge} N^{\wedge} N\right)(\mathrm{C} \equiv \mathrm{C}-\mathrm{R})\right]^{20,25,29,30} \quad\left({ }^{t} \mathrm{Bu}_{2}-C^{\wedge} N^{\wedge} N=4,4^{\prime}-\right.$ di(tert-butyl)-6-phenyl-2,2'-bipyridine) were chosen in order to form neutral $\mathrm{Pt}$ (II) species that are advantageous over cationic complexes in terms of affinity for $\mathrm{M}^{n+}$ ions. The presence of the tert-butyl groups sterically inhibits undesirable intermolecular interactions that frequently lead to concentration-dependent self-quenching of the luminescence. ${ }^{29}$ The free alkynes were first constructed and subsequently coordinated to the $\left[\mathrm{Pt}\left({ }^{t} \mathrm{Bu}_{2}\right.\right.$ $\left.C^{\wedge} N^{\wedge} N\right)$ ] precursor. ${ }^{29}$ The macrocyclic pyridine-containing ligand 3 was prepared in an overall yield of $30 \%$ from chelidamic acid, according to adapted literature procedures, ${ }^{26-28}$ comprising five synthetic steps (Scheme 1). ${ }^{1}$

Reaction of $\left[\mathrm{Pt}\left({ }^{t} \mathrm{Bu}_{2}-C^{\wedge} N^{\wedge} N\right) \mathrm{Cl}\right]$ with 3 or 4-ethynylpyridine, ${ }^{31}$ in the presence of catalytic amounts of $\mathrm{CuI}(10 \mathrm{~mol} \%)$ in

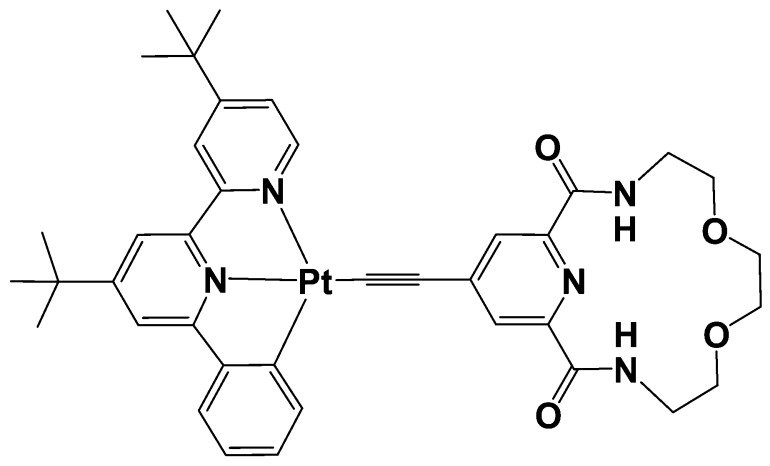

1

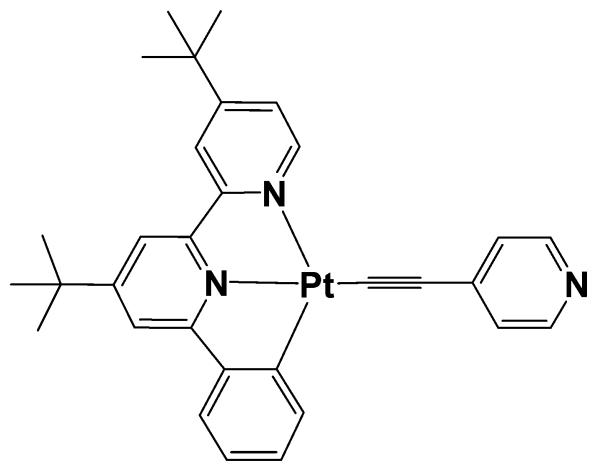

2

Chart 1 
Table 1 Spectroscopic properties of $\mathbf{1}$ and $\mathbf{2}$

\begin{tabular}{llll}
\hline & Absorption $^{a} \lambda_{\max } / \mathrm{nm}\left(\varepsilon / 10^{3} \mathrm{dm}^{3} \mathrm{~mol}^{-1} \mathrm{~cm}^{-1}\right)$ & Emission, ${ }^{b} 298 \mathrm{~K} \lambda_{\max } / \mathrm{nm}\left(\tau / \mathrm{ns} ; \phi^{c}\right)$ & Emission, $77 \mathrm{~K}^{d} \lambda_{\max } / \mathrm{nm}(\tau / \mu \mathrm{s})$ \\
\hline $\mathbf{1}$ & $322(23.1) ; 350(13.7) ; 410(7.1)$ & $566(600 ; 0.074)$ & $515,550,595(4.7)$ \\
$\mathbf{2}$ & $330(18.6) ; 360(11.8) ; 430(6.6)$ & $569(540 ; 0.063)$ & $513,550,594(5.7)$
\end{tabular}

${ }^{a} \mathrm{CH}_{3} \mathrm{CN}, 10^{-5} \mathrm{M} .{ }^{b}$ Deoxygenated $\mathrm{CH}_{3} \mathrm{CN}, 10^{-6} \mathrm{M}, 298 \mathrm{~K}, \lambda_{\text {exc }}=420 \mathrm{~nm} .{ }^{c}$ Emission quantum yields were determined using $\left[\mathrm{Ru}(\mathrm{bpy})_{3}\right] \mathrm{Cl}{ }_{2} .{ }^{d} \mathrm{EPA}$ diethylether/isopentane/ethanol, $2: 2: 1 \mathrm{v} / \mathrm{v}$.

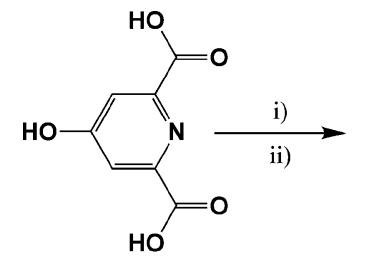

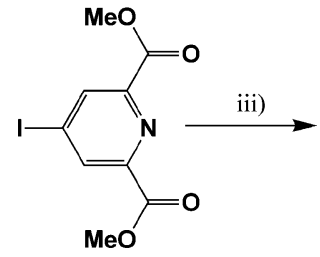

4

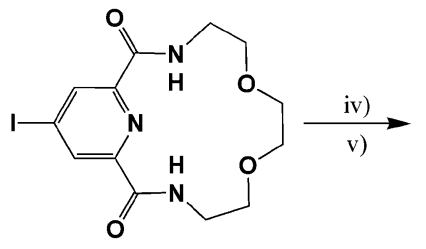

5

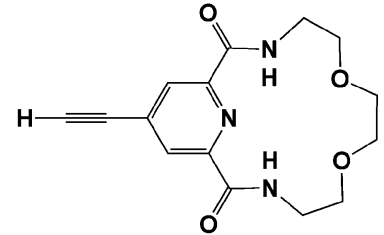

3

Scheme 1 Synthetic route to 3. (i) $\mathrm{H}_{2} \mathrm{SO}_{4}, \mathrm{MeOH}$, reflux, $12 \mathrm{~h}$ (59\%). (ii) $n \mathrm{Bu}_{4} \mathrm{NI}, \mathrm{P}_{2} \mathrm{O}_{5}$, toluene, reflux, $5 \mathrm{~h}$ ( $90 \%$ ). (iii) 2,2'-(ethylenedioxy)-bisethylamine, $\mathrm{MeOH}, 7 \mathrm{~d}\left(70 \%\right.$ ). (iv) TMSA, $\mathrm{Pd}\left(\mathrm{PPh}_{3}\right)_{2} \mathrm{Cl}_{2}$, CuI, THF/Et $\mathrm{N}, 12$ h. (v) $\mathrm{K}_{2} \mathrm{CO}_{3}, \mathrm{CH}_{2} \mathrm{Cl}_{2} / \mathrm{MeOH} / \mathrm{H}_{2} \mathrm{O}, 2 \mathrm{~h}(80 \%)$.

$\mathrm{CH}_{2} \mathrm{Cl}_{2}$ and diisopropylamine led to acetylide derivatives $\mathbf{1}$ and 2, respectively, in good yield. Absorption and emission spectra of complexes 1 and 2 were recorded in $\mathrm{CH}_{3} \mathrm{CN}$ at $298 \mathrm{~K}$ and in an ether/isopentane/ethanol glass (EPA) at $77 \mathrm{~K}$ (Table 1 and Fig. 1).

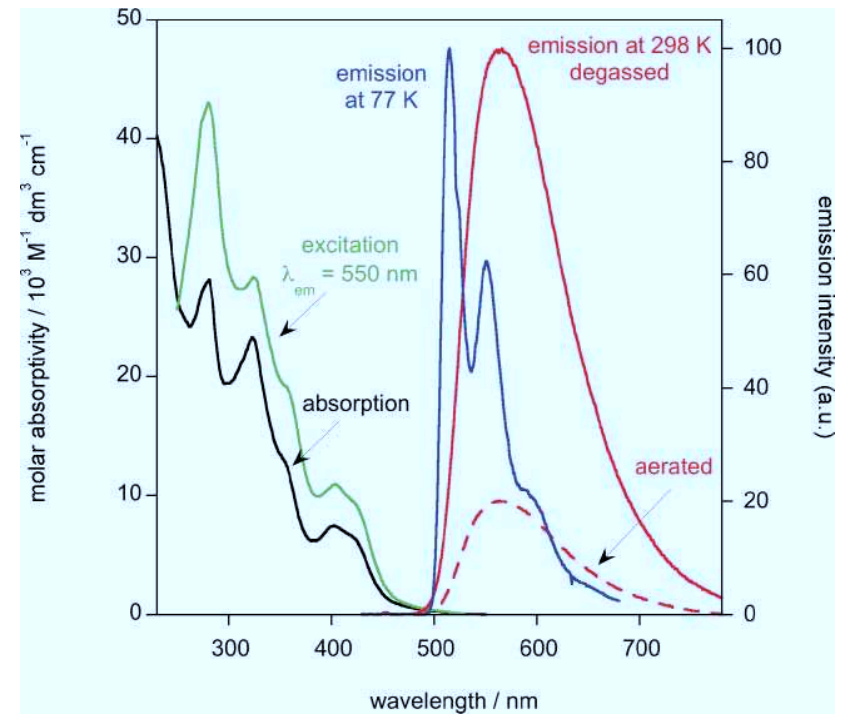

Fig. 1 Electronic absorption and luminescence excitation $\left(\lambda_{\mathrm{em}}=550 \mathrm{~nm}\right)$ spectra of complex 1 in $\mathrm{CH}_{3} \mathrm{CN}$ solvent, and the normalized emission spectra $\left(\lambda_{\text {exc }}=420 \mathrm{~nm}\right)$ under the same conditions and in EPA glass at $77 \mathrm{~K}$.

The electronic absorption spectra of $\mathbf{1}$ and $\mathbf{2}$, in acetonitrile solution exhibit intense absorption bands in the 330-360 nm range and less intense bands in the $370-450 \mathrm{~nm}$ range (Table 1). With reference to previous spectroscopic work on cyclometallated platinum(II) complexes featuring alkynyl ligands, ${ }^{30,32}$ the highenergy intense absorption bands are assigned to intraligand (IL) transitions of the phenylbipyridine and alkynyl ligands. The broad low-energy bands in the visible region are assigned as $\left[\mathrm{d} \pi(\mathrm{Pt}) \rightarrow \pi^{*}\left({ }^{t} \mathrm{Bu}_{2}-C^{\wedge} N^{\wedge} N\right)\right]$ MLCT transitions, with mixing of some acetylide to diimine ligand $\left[\pi(\mathrm{C} \equiv \mathrm{C}) \rightarrow \pi^{*}\left({ }^{t} \mathrm{Bu}_{2}-C^{\wedge} N^{\wedge} N\right)\right]$ ligand-to-ligand charge-transfer ( $\left.\mathrm{L}^{\prime} \mathrm{LCT}\right)$ character ( $\mathrm{L}^{\prime}$ represents the acetylide ligand and $\mathrm{L}$ the phenylbipyridine). The observed $20 \mathrm{~nm}$ blue-shift in the MLCT/L'LCT absorption band in 1 compared to $\mathbf{2}$ is likely to be the result of the electronic withdrawing effect of the two amido groups of the macrocycle and/or the presence of hydrogen bonding interactions between pyridine $\mathrm{N}$ and amide $\mathrm{N}-\mathrm{H}$ lowering the HOMO energy.

Irrespective of the excitation wavelength $\left(\lambda_{\mathrm{exc}}=310-450 \mathrm{~nm}\right)$, the room-temperature emission spectra of complexes $\mathbf{1}$ and $\mathbf{2}$ exhibit structurally unresolved spectra with maxima at 566 and $569 \mathrm{~nm}$, respectively, and emission quantum efficiencies of the order of $6-7 \%$. The lifetime of emission from the excited state is of the order of $500 \mathrm{~ns}$. The excitation spectra of the complexes $\left(\lambda_{\mathrm{em}}=550 \mathrm{~nm}\right)$ match perfectly with the absorption spectra, indicating that population of the emissive state from higher-lying singlet and triplet states is fast and efficient. The large Stokes shift $\left(\sim 6600 \mathrm{~cm}^{-1}\right)$ and the luminescence lifetimes approaching the microsecond range are typical of emission origins with triplet parentage. The emission energies are blue-shifted from related $\left[\operatorname{Pt}\left(C^{\wedge} N^{\wedge} N\right)(\mathrm{C} \equiv \mathrm{CAr})\right]$ derivatives (for example $\mathrm{Ar}=\mathrm{Ph}: \lambda_{\mathrm{em}}=$ $582 \mathrm{~nm}) .{ }^{29}$ The pyridine electron-withdrawing group, via electronic conjugation of the $\mathrm{C} \equiv \mathrm{C}$ triple bond, may stabilize the Pt-based HOMO leading to blue-shifted emissions. This is in accordance with the tunability of the emission energies, depending on the nature of the acetylide substituent. As is frequently observed with related polypyridine complexes, vibronic structure in the spectra at $77 \mathrm{~K}$ provides further evidence in support of the involvement of the phenylbipyridyl ligand in the emissive excited state. ${ }^{29,30}$ In accordance with previous studies, ${ }^{29,30}$ the emission of $\mathbf{1}$ and $\mathbf{2}$ is assigned to ${ }^{3}$ MLCT excited states to which acetylide-todiimine L'LCT transitions may also contribute.

Effects on the absorption spectrum of $\mathbf{1}$ and $\mathbf{2}$ upon addition of metal cations $\left(\mathrm{Ba}^{2+}, \mathrm{Mg}^{2+}, \mathrm{Ni}^{2+}, \mathrm{Zn}^{2+}, \mathrm{Cd}^{2+}, \mathrm{Pb}^{2+}\right)$ as their perchlorate salts were studied. None of the studied cations leads to changes in the absorption spectrum of $\mathbf{2}$ in acetonitrile. Similarly, addition of $\mathrm{Ba}^{2+}, \mathrm{Mg}^{2+}, \mathrm{Ni}^{2+}, \mathrm{Zn}^{2+}$, and $\mathrm{Cd}^{2+}$, up to 50 equiv., to the solution of $\mathbf{1}$ in acetonitrile does not lead to any change in its absorption spectrum (ESI, Fig. S1†), nor does addition of 


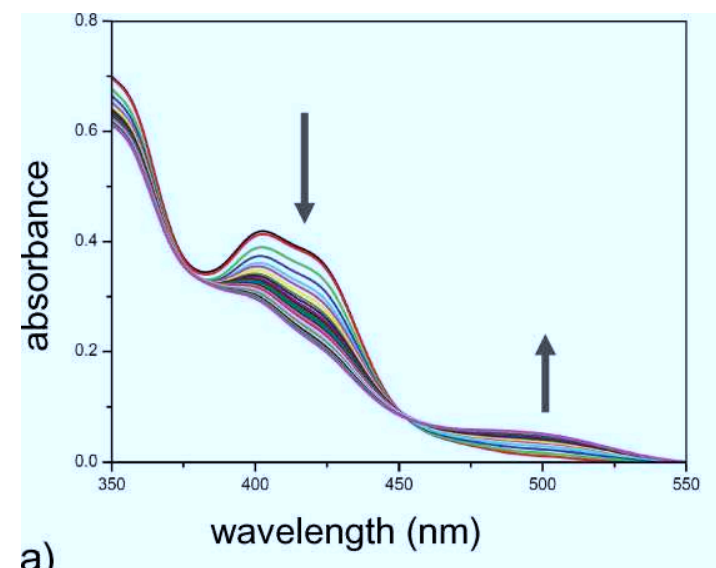

a)

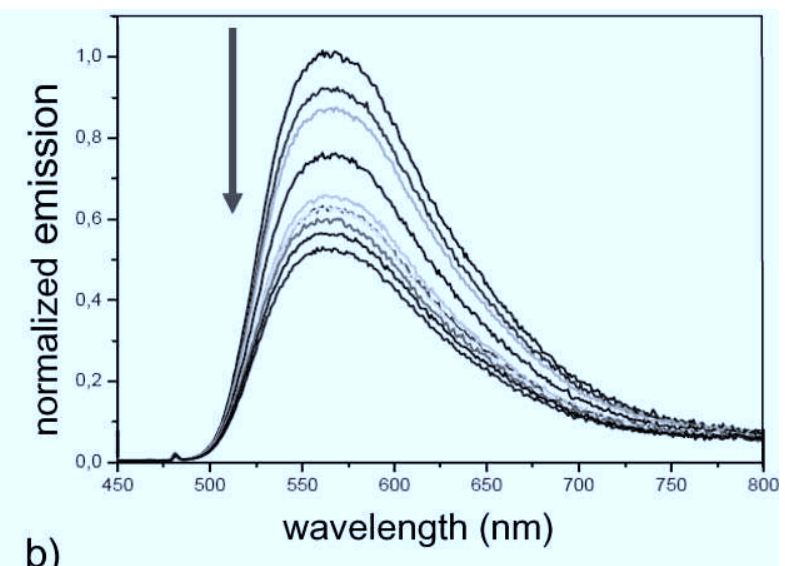

b)

Fig. 2 (a) Absorption spectral changes of $\mathbf{1}\left([\mathbf{1}]=5.7 \times 10^{-5} \mathrm{M}\right.$ in $\left.\mathrm{CH}_{3} \mathrm{CN}\right)$ with $\mathrm{Pb}\left(\mathrm{ClO}_{4}\right)_{2}\left(\left[\mathrm{~Pb}\left(\mathrm{ClO}_{4}\right)_{2}\right]=1.0 \times 10^{-2} \mathrm{M}, 1 \mu \mathrm{L}\right.$ added each time $)$ as a function of $\mathrm{Pb}^{2+}$ concentration (0 to 5 equiv.). (b) Variation of the emission spectrum of 1 with $\mathrm{Pb}\left(\mathrm{ClO}_{4}\right)_{2}$ in $\mathrm{CH}_{3} \mathrm{CN}$ solvent; $[1]=5.7 \times 10^{-5} \mathrm{M} ;(3 \mathrm{~mL})$ $\left[\mathrm{Pb}\left(\mathrm{ClO}_{4}\right)_{2}\right]=1.0 \times 10^{-2} \mathrm{M}$, addition $3 \mu \mathrm{L}$ each time. Excitation at $450 \mathrm{~nm}$ (isosbestic point).

an excess of trifluoromethanesulfonic acid. Strikingly, however, addition of $\mathrm{Pb}^{2+}$ cations to $\mathbf{1}$ in acetonitrile results in significant changes of the absorption spectrum (Fig. 2a). The broad band at $370-450 \mathrm{~nm}$ strongly decreases monotonically throughout the addition while a new band centred at $500 \mathrm{~nm}$ concomitantly grows in with increasing $\mathrm{Pb}^{2+}$ concentration. A well-defined isosbestic point at $450 \mathrm{~nm}$ is shown, suggestive of a ground-state equilibrium of the free 1 and lead-complexed $1-\mathrm{Pb}^{2+}$ species. A binding constant $(\log K)$ of $4.44( \pm 0.07)$ was determined from these plots corresponding to a $1: 1$ stoichiometry, in agreement with the mass spectrum of $1-\mathrm{Pb}^{2+}$ (see ESI). $\dagger$

In addition, a remarkable luminescence decrease $\$$ at $570 \mathrm{~nm}$ $\left(\lambda_{\mathrm{exc}}=450 \mathrm{~nm}\right)$ was observed upon addition of lead cations, while the shape, the lifetime and the energy of the emission band did not change (Fig. 2b). A binding constant $(\log K)$ of $3.30( \pm 0.07)$ was determined from these plots. Interestingly, upon irradiation into the new lower-energy absorption band $\left(500 \mathrm{~nm}, \mathrm{CH}_{3} \mathrm{CN}\right)$ attributed to complex 1- $\mathrm{Pb}^{2+}$, no emission is observed.

The above results demonstrate that the pyridine-based macrocycle in $\mathbf{1}$ is valuable to specifically bind lead cations. The efficiency of the macrocyclic ligand toward $\mathrm{Pb}^{2+}$ can tentatively be ascribed to the ionic radius difference between lead ions $(1.20 \AA)$ and other cations, pyridine dicarboxamide being a ligand suited to relatively large ions. ${ }^{33-34}$ This size effect is also probably enhanced by the different degree of softness of the metal ions. This could explain why $\mathrm{Cd}^{2+}$ gives no effect with $\mathbf{1}$, in contrast to the somewhat softer $\mathrm{Pb}^{2+} .{ }^{35}$ We assume that the $1: 1$ complexation of $\mathrm{Pb}^{2+}$ ions occurs via the nitrogen atom of the pyridine ring and leads to a stronger electron-acceptor capability of the pyridine ring. The residual emission, the characteristics ( $\lambda_{\mathrm{em}}$ and $\tau$ ) of which are unchanged, can be attributed to the remaining unbound Pt complex 1, still present in solution (ESI, Fig. S3). $\dagger$ The significantly lower affinity (by one order of magnitude) of $\mathbf{1}$ for $\mathrm{Pb}^{2+}$ ions in the excited state compared to that of the ground state is attributed to a weaker electron density in the pyridyl ring. Such an electronic effect might be expected to lead to a blue-shifted MLCT/L'LCT transition band, as it is the case for $\mathbf{1}$ with respect to $\mathbf{2}$. Instead, a new lowenergy band (centered at $c a .500 \mathrm{~nm}$ ) is generated. We suggest that the new band due to lead-complexed $1-\mathrm{Pb}^{2+}$ could be assigned to an $\mathrm{ML}^{\prime} \mathrm{CT}\left[\mathrm{d} \pi(\mathrm{Pt}) \rightarrow \pi^{*}(\mathrm{C} \equiv \mathrm{C}-\mathrm{py})\right]$ transition. $\S$ This non-emissive state becomes the lower-lying excited state, as the result of the lowering of the energy of the $\pi^{*}$ orbitals of the $\mathrm{C} \equiv \mathrm{C}$-py fragment upon lead binding, i.e. a switch of $\mathrm{CT}$ to the opposite direction.

In summary, we have prepared cyclometallated platinum(II) complexes containing pyridyl-acetylide ligands and demonstrated the selective influence of lead binding on luminescence. The present strategy proves that cyclometallated platinum-acetylide complexes are promising probes for a wide range of substrates by incorporating the appropriate receptor.

\section{Notes and references}

$\$$ Treatment of 2 with trifluoromethanesulfonic acid led to quenching of its emission as observed in similar complexes. ${ }^{36}$

$\S$ Since a $1: 1 \mathrm{~Pb}^{2+}$-binding stoichiometry is observed, the formation of Pt $\cdots$ Pt interactions, which might lead to a low-energy MMLCT transition, can be ruled out, since this would involve a $2: 1$ stoichiometry. ${ }^{37}$

1 A. P. de Silva, H. Q. Gunaratne, T. Gunnlaugsson, A. J. Huxley, C. P. McCoy, J. T. Rademacher and T. E. Rice, Chem. Rev., 1997, 97, 1515.

2 C. W. Rogers and M. O. Wolf, Coord. Chem. Rev., 2002, 233-234, 341.

3 W. Goodall and J. A. G. Williams, J. Chem. Soc., Dalton Trans., 2000, 2893.

4 M. L. Ho, F. M. Hwang, P. N. Chen, Y. H. Hu, Y. M. Cheng, K. S. Chen, G. H. Lee, Y. Chi and P. T. Chou, Org. Biomol. Chem., 2006, 4, 98.

5 M.-L. Ho, Y.-M. Cheng, L.-C. Wu, P.-T. Chou, G.-H. Lee, F.-C. Hsu and Y. Chi, Polyhedron, 2007, 26, 4886.

6 L. Huynh, Z. Wang, J. Yang, V. Stoeva, A. Lough, I. Manners and M. A. Winnik, Chem. Mater., 2005, 17, 4765.

7 M.-J. Li, Z. Chen, N. Zhu, V. W.-W. Yam and Y. Zu, Inorg. Chem., 2008, 47, 1218.

8 M.-J. Li, C.-C. Ko, G.-P. Duan, N. Zhu and V. W.-W. Yam, Organometallics, 2007, 26, 6091.

9 Z. H. Lin, Y. G. Zhao, C. Y. Duan, B. G. Zhang and Z. P. Bai, Dalton Trans., 2006, 3678.

10 F. Zapata, A. Caballero, A. Espinosa, A. Tárraga and P. Molina, Org. Lett., 2008, 10, 41.

11 Q. Zhao, T. Cao, F. Li, X. Li, H. Jing, T. Yi and C. Huang, Organometallics, 2007, 26, 2077.

12 R. McGuire Wilson, H. Michael, J. J. Nash, P. E. Fanwick and D. R. McMillin, Inorg. Chem., 2008, 47, 2946.

13 F. N. Castellano, I. E. Pomestchenko, E. Shikhova, F. Hua, M. L. Muro and N. Rajapakse, Coord. Chem. Rev., 2006, 250, 1819. 
14 W. Lu, M. C. W. Chan, N. Zhu, C.-M. Che, Z. He and K.-Y. Wong, Chem.-Eur. J., 2003, 9, 6155.

15 Y. Fan, Y.-M. Zhu, F.-R. Dai, L.-Y. Zhang and Z.-N. Chen, Dalton Trans., 2007, 3885.

16 W. S. Tang, X. X. Lu, K. M.-C. Wong and V. W. W. Yam, J. Mater. Chem., 2005, 15, 2714.

17 K. M. C. Wong and V. W. W. Yam, Coord. Chem. Rev., 2007, 251, 2477.

18 K. M.-C. Wong, W.-S. Tang, X.-X. Lu, N. Zhu and V. W.-W. Yam, Inorg. Chem., 2005, 44, 1492.

19 P. Wu, E. L. M. Wong, D. L. Ma, G. S. M. Tong, K. M. Ng and C. M. Che, Chem.-Eur. J., 2009, 15, 3652.

20 Q. Z. Yang, L. Z. Wu, H. Zhang, B. Chen, Z. X. Wu, L. P. Zhang and C. H. Tung, Inorg. Chem., 2004, 43, 5195.

21 X. Han, L.-Z. Wu, G. Si, J. Pan, Q.-Z. Yang, L.-P. Zhang and C.-H. Tung, Chem.-Eur. J., 2007, 13, 1231.

22 D. L. Rochester, S. Develay, S. Zalis and J. A. G. Williams, Dalton Trans., 2009, 1728.

23 V. W. W. Yam, R. P. L. Tang, K. M. C. Wong and K. K. Cheung, Organometallics, 2001, 20, 4476.

24 Z. Ji, Y. Li and W. Sun, Inorg. Chem., 2008, 47, 7599.

25 P.-H. Lanoë, J.-L. Fillaut, L. Toupet, J. A. G. Williams, H. Le Bozec and V. Guerchais, Chem. Commun., 2008, 4333.

26 A. Picot, C. Feuvrie, C. Barsu, F. Malvolti, B. Le Guennic, H. Le Bozec, C. Andraud, L. Toupet and O. Maury, Tetrahedron, 2008, 64, 399.
27 D. T. Gryko, P. Piatek, A. Pecak, M. Palys and J. Jurczak, Tetrahedron, 1998, 54, 7505.

28 A. Szumna, D. T. Gryko and J. Jurczak, J. Chem. Soc., Perkin Trans. 2, $2000,1553$.

29 W. Lu, B.-X. Mi, M. C. W. Chan, Z. Hui, C.-M. Che, N. Zhu and S.-T. Lee, J. Am. Chem. Soc., 2004, 126, 4958.

30 M. L. Clark, S. Diring, P. Retailleau, D. R. McMillin and R. Ziessel, Chem.-Eur. J., 2008, 14, 3931.

31 R. Ziessel, J. Suffert and M.-T. Youinou, J. Org. Chem., 1996, 61, 6535.

32 W. Lu, B. X. Mi, M. C. W. Chan, Z. Hui, N. Y. Zhu, S. T. Lee and C. M. Che, Chem. Commun., 2002, 206.

33 R. T. Gephart, N. J. Williams, J. H. Reibenspies, A. S. De Sousa and R. D. Hancock, Inorg. Chem., 2009, 48, 8201.

34 V. N. Romanovskiy, V. A. Babain, M. Y. Alyapyshev, V. Smirnov, R. S. Herbst, J. D. Law and T. A. Todd, Sep. Sci. Technol., 2006, 41, 2111.

35 G. Arena, A. Contino, E. Longo, D. Sciotto and G. Spoto, J. Chem. Soc., Perkin Trans. 2, 2001, 2287.

36 T. K. Ronson, T. Lazarides, H. Adams, S. J. A. Pope, D. Sykes, S. Faulkner, S. J. Coles, M. B. Hursthouse, W. Clegg, R. W. Harrington and M. D. Ward, Chem.-Eur. J., 2006, 12, 9299.

37 H. S. Lo, S.-K. Yip, N. Zhu and V. W.-W. Yam, Dalton Trans., 2007, 4386. 